\title{
THE ROLE OF LOCAL COMMUNITIES IN THE CO-CREATION OF INNOVATIONS FOR INCLUSIVE AND SUSTAINABLE TERRITORIAL DEVELOPMENT: THE MADONIE CASE
}

\author{
Jelena Mazaj ${ }^{1,2}$, Silvana Di Bono ${ }^{3}$, Arabella Mocciaro Li Destri ${ }^{4}$ \\ ${ }^{1}$ University of Palermo, Viale delle Scienze Ed. 13 Palermo, Italy \\ ${ }^{2}$ Higher Education and Research Unit, CESIE, via Roma 94, Palermo, Italy \\ ${ }^{3}$ ARCA Consortium, Viale delle Scienze Ed. 16, 90128 Palermo, Italy \\ ${ }^{4}$ University of Palermo, Viale delle Scienze Ed. 13 Palermo, Italy \\ E-mails: ${ }^{1}$ jelena.mazaj@cesie.org (corresponding author); jmazaj@gmail.com; \\ 3sdibono@consorzioarca.it; ${ }^{4}$ arabella.mocciaro@unipa.it
}

\begin{abstract}
Rapid social, political, geographic and economic changes in the world, linked to technological revolution of the last century are followed by wide positive and negative changes in people lives and R\&I processes (open markets, digitalisation, resource scarcity, poverty, etc.). Looking for solutions for a better future, the EU policy agenda for 2030 promotes actions which foster cocreation of innovations, targets sustainability and Sustainable Development Goals. As such, EU regions are motivated to enhance and capitalise local competences and resources to achieve a social impact and tackle glocal challenges more effectively. Such reinforcement of local development is possible applying interdisciplinarity in R\&I processes, through the co-design of innovation by different stakeholders and the empowerment of informal innovation actors.

This article presents a methodological framework applied to the co-creation of innovation involving local stakeholders in the Madonie region in Sicily, the results gained and the role of the intermediate body - a Competence Cell responsible for facilitation of such collaboration. This process has been implemented in the frame of the Horizon 2020 FoTRRIS project.
\end{abstract}

Keywords: innovation, co-creation, inclusive and sustainable development, competence cell.

JEL Classification: O3.

\section{Introduction}

Technological revolution and rapid geographical, social, political, economic changes in the world in 20 th century are followed by wide positive and negative changes in people lives and R\&I processes, for example: open markets, digitalisation, resource scarcity, poverty. Globalisation and growth demand in products and services, product consumption shaped EU socio-economic model in a negative way. M. Deblonde presents data from the European Environment Agency, which indicates that between 2000 and 2007 the total use of natural resources and production of waste increased by $34 \%$, such correlation is related to economic growth and increasing welfare. As a result, such increases make negative impact on ecology and quality of life across the planet (Deblonde, 2015). According to A. Snick "the plan is reaching tipping points where what once seemed to be beneficial, at a larger time scale appears to threaten our very wellbeing and survival". (Snick, 2017). European Environmental Agency presents facts: "global consumption exceeds the planet's regenerative capacity by more than 50\%', global materials use may double by 2030 , world demand for energy and water are both projected to rise by between $30 \%$ and $40 \%$ over the next 20 years, total demand for food is projected to grow by about $60 \%$ between now and 2050 ". On policy level, the sustainable development is seen not anymore as a parallel task in correspondence to R\&I processes, but its a core one, however very challenging one. (European Environmental Agency, 2015).

To foster positive changes, in September 2015193 member states of the United Nations (UN) adopted 17 Sustainable Development Goal for 2030 based on the pillars: economic, environmental and social. With this agenda, all the member states undertake responsibility to create "conditions for sustainable, inclusive and sustained economic growth, shared prosperity and 
decent work for all, taking into account different levels of national development and capacities". However, to reach them it is important to take into account that each country has a different vision, models and instruments to overcome national obstacles and priorities (United Nations, 2015; Annan-Diab \& Molinari, 2017). Based on these challenges, which should be deal with, it should be mentioned that the start point for sustainable solutions has a glocal approach and, in such nonlinear contest, a society should look for innovative tools for the integration of the goals into reality. Interdisciplinary and interdisciplinary are one of the key aspects to evaluate in this case. It helps to figure out the complex challenges through the integration of different approaches in one system and sustainable development interactions among several disciplines (Annan-Diab \& Molinari, 2017), promoting co-creation between local stakeholders in R\&I as a normative.

This article presents a methodological framework applied to the co-creation of innovation for local challenge involving different stakeholders in the Madonie region in Sicily and the results gained in the frame of the Horizon 2020 "Fostering Transition towards Responsible Research and Innovation System" (FoTRRIS) project. The role of a competence cell to enhance this process is presented.

\section{Responsible Research and Innovation}

In the EU policy level, debates about how to improve sustainably from R\&I and rethink R\&I processes are more and more active, including these aspects in EU policy documents, as priorities in funding programmes and looking for innovative, but sustainable initiatives. According to A. Snick "The EU encourages research and innovation to find solutions to the big crises. Specifically the concept of Responsible Research and Innovation (RRI) is coined to denote R\&I that deals with sustainability and is structured around six themes: ethics, gender equality, citizen engagement, education, open knowledge and governance" (Snick, 2017). Dr. phil. René von Schomberg (philosopher and leader of the EU Open Science group) describes the RRI as "a transparent, interactive process by which societal actors and innovators become mutually responsive to each other with a view to the (ethical) acceptability, sustainability and societal desirability of the innovation process and its marketable products (in order to allow a proper embedding of scientific and technological advances in our society" (Von Schomberg, 2013). With the era of the RRI, answering to the question: "what does it really mean "responsibility" in R\&I and how to implement RRI? " will be on the EU arena for a long time. But even today, it is visible what are the core meanings in the presented definition: "establishment of common language" between different actors, openness for close cooperation, appearance of new governance models, common agreement on the goal, creation of desirable and sustainable R\&I outcomes with and for society.

However, we cannot say that the way of rethinking science is a new vision. It appeared more than 20 years ago due to limited investments in research, technological resolution and its outcomes concerning scarcity of natural resources. Then, science-society cooperation has been fostered to find new ways of interactions and contributions. Understanding of science became broader, it has been connected with societal actors (both: non formal and formal) and of knowledge as being the result of co-creation practices. The future objective of the EU is to increase investments in education about STEM and foster RRI in the future (Mejgaard, 2018; EC, 2017). In literature, there are different reasons mentioned, why science is important: it is the heart of the R\&I system and supports competitiveness in global knowledge economy; it supports policy makers in the decision-making process presenting evidence; it is the creation by which the information society can understand its results and terms and even more, "science is subjected to inclusive governance arrangements, in which societal actors and citizens actively participate in prioritisation and assessment" (EC, 2017). This brings us to the core of the responsible research and innovation, which according to M. Deblonde is a "combined future and goal-oriented responsibility for sustainable development" (Deblonde, 2015). She also underlines, that R\&I should not "focus on the development of new and emergent science and technology". It should be oriented to "societal demand-driven strategy", this means - targeting a locally specific global sustainability challenge, reempowering citizens and researchers, including them in democratic R\&I process. Only inviting groups of different actors for cooperation and pooling their different knowledge and experiences will help to get a sustainable solution. It means that RRI should be based on 
transdisciplinary. The author gives more detailed explanation for this:

- "Local sustainability challenges cannot one-sidedly be solved from a particular disciplinary perspective, for two reasons.

- Disciplinary perspective always considers reality from a specific theoretical frame or paradigm and, consequently, challenges first have to be translated into disciplinary terms in order to make them fit for a scientific 'solution'. This translation is more often than not incompatible with stakeholders' understanding of the challenge.

- Increasing disciplinary specialisation and fragmentation easily leads to reallife challenges either being translated in a reductionist way or being neglected because the disciplinary perspective prevents professional knowledge actors to perceive it.

Transdisciplinarity helps the research and innovation community to deal with the prescriptive limitations of scientific knowledge and technological know-how" (Deblonde, 2015). Which innovation community? Nowadays this question is partly covered by open and social innovations.

\section{Open Innovations vs Social Innovations}

Research on open innovation and social innovation has gained special attention in the last decade. There are plethora of descriptions and thoughts about these two different but at the same time, complementary concepts.

Open innovation has been described by $\mathrm{H}$. Chesbrough as "a paradigm that assumes that firms can and should use external ideas as well as internal ideas, and internal and external paths to market, as the firms look to advance their technology" (Chesbrough, 2003). Öberga and Alexanderc (2018) present a broader definition, saying, that open innovation are results of cost reduction for technology development, reduced risk for market entry, to achieve economies of scale for production, reduce lead times for product or service development throughout the promoted shared learning.

Meantime, the EU presents it as a co-creation process between all actors through free knowledge circulation and transformation into products and services, that support a growth of new markets and entrepreneurship the enterpreneural culture. Additionally the Commission outlines its distinctive features innovation is open if developed in dynamic, networked, multicollaborative ecosystems. It is an output of a complex co-creation process based on the whole socio-economic environment, which is based on three elements:

- linking the ideas and knowledge from different actors (R\&I organisations, business, policy makers, CSOs, etc.) to co-develop new products and identify solutions to societal needs;

- creating economic and social value, including a citizen and user-centered approach;

- capitalising on the implications of trends such as digitalisation, mass participation and collaboration (EC RTD, 2015).

Meantime, Nicholls and Dees (2015) in their common work, investigated on social innovation and listed many definitions associated to it, below are presented three different opinions, stated by different authors:

1. Mumford (2002): social innovation refers to the generation and implementation of new ideas about how people should organize interpersonal activities, or social interactions, to meet one or more common goals.

2. Westley and Antadze (2010): Social innovation is a complex process of introducing new products, processes or programs that profoundly change the basic routines, resource and authority flows, or beliefs of the social system in which the innovation occurs. Such successful social innovations have durability and broad impact.

3. OECD (2011): Social innovation is distinct from economic innovation because it is not about introducing new types of production or exploiting new markets in itself but is about satisfying new needs not emerging on the market (even if markets intervene later) or creating new, more satisfactory ways of integration in terms of giving people a place and a role in production.

The main difference between open and social innovation is that social innovations are not looking for a place on the market, they are oriented to explicitly to the social and public good (Matei \& Antonie, 2015). The table presented below gives a short overview of main actors, objectives, processes, results of both concepts (see Table 1). 
Table 1. Main characteristics of open innovation and social innovation (source: Martins Montreiro \& Henrique de Souza Bermejo, 2015)

\begin{tabular}{|c|c|c|}
\hline & Social innovation & Open innovation \\
\hline Actors & $\begin{array}{l}\text { Individuals } \\
\text { (Lettice \& } \\
\text { Parekh, 2010), } \\
\text { policy makers, } \\
\text { and governments } \\
\text { (Pol \& Ville, } \\
\text { 2009). }\end{array}$ & $\begin{array}{l}\text { Mainly private } \\
\text { companies } \\
\text { (Huizingh, 2011), } \\
\text { involving users of } \\
\text { innovations } \\
\text { (Baldwin \& Von } \\
\text { Hippel, 2010). }\end{array}$ \\
\hline \multirow[t]{2}{*}{$\begin{array}{l}\text { Objec- } \\
\text { tives }\end{array}$} & $\begin{array}{l}\text { Structural goals: } \\
\text { social change } \\
\text { (Cajaiba- } \\
\text { Santana, 2013). }\end{array}$ & \multirow{2}{*}{$\begin{array}{l}\text { Products, services, } \\
\text { systems, and models } \\
\text { aimed at the users' } \\
\text { demand (Baldwin \& } \\
\text { Von Hippel, 2010). }\end{array}$} \\
\hline & $\begin{array}{l}\text { Instrumental: } \\
\text { create technical } \\
\text { articles that meet } \\
\text { a social need } \\
\text { (Taylor, 1970). }\end{array}$ & \\
\hline Process & \begin{tabular}{|l|} 
Process: \\
collective action \\
(Neumeier, 2012) \\
and intentional \\
innovation by \\
stakeholders \\
(Cajaiba- \\
Santana, 2013).
\end{tabular} & $\begin{array}{l}\text { Collaborative using } \\
\text { some methodology } \\
\text { (Costumer partner, } \\
\text { Crowdsourcing, } \\
\text { Crowstorming, etc.) } \\
\text { (Loren, 2011) }\end{array}$ \\
\hline $\begin{array}{l}\text { Expected } \\
\text { results }\end{array}$ & \begin{tabular}{|l|} 
Results are \\
expected to \\
provide benefits \\
to society \\
through products, \\
processes or \\
services that \\
meet a social \\
need (Taylor, \\
1970), or social \\
changes that \\
institutionalize a \\
new social \\
practice \\
(Howaldt et al., \\
2010).
\end{tabular} & $\begin{array}{l}\text { New products, } \\
\text { services, systems, } \\
\text { and more effective } \\
\text { models are } \\
\text { developed in the } \\
\text { context of more } \\
\text { porous } \\
\text { organizational } \\
\text { structures that } \\
\text { feature greater } \\
\text { absorption capacity } \\
\text { and involvement of } \\
\text { various stakeholders } \\
\text { in the innovation } \\
\text { process (Chalmers, } \\
\text { 2013). }\end{array}$ \\
\hline
\end{tabular}

These two concepts are separated in the literature, due to two main differences:

- open innovation aims to develop products with users to get a profit for both parties. The co-creation process is based on specific reward strategies.

- social innovation is for society community, based on shared values and reward is not expected. Such innovation process can start everywhere and does not need a specific framework.
However, the starting point and the core focus of both concepts are the same: final outputs result from the co-creation process. In recent literature emerging interpretations of both concepts can be found - open social innovation, which combines characteristics of both earlier presented concepts - using open innovation methodology to enhance the creation and diffusion of social innovations (Martins Montreiro \& Henrique de Souza Bermejo, 2015).

Nonetheless, it is crucial to support the transition towards more dynamic knowledge circulation. It is also essential to cultivate and feed in co-creation ecosystems, making science reliable, efficient and responsive to the needs of society.

\section{Inclusive and Sustainable territorial development for the EU Policy Agenda for 2030}

As we can see, external actors contribute to the development of research agendas. How to boost effectively citizens participation in R\&I is one of the key questions on EU policy level and several tips are given, such as: to have a clear aim and method to apply, share responsibilities, be transparent, to have sufficient time, to be open and sometimes even more important is not the result of the co-creation process, but social change which starts after such cooperation, which helps to collect information about social issues in a community, identify R\&I focus areas, develop innovative practices, to expand $R \& I$ in non-expert communities, to make co-creation process more inclusive and participatory (OECD, 2103).

The enhancement of local competences and resources to achieve a social impact and tackle glocal challenges more effectively in many EU regions has been also reached through increased interdependency among urban and inner areas, especially in environmental domains and service provision. The recognition of this linkage led to new models of territorial identity management taking benefit from cross-fertilisation and shared use of local material resources and intangible assets, connecting urban creative communities with rural social innovation actors (AA.VV. Strategy for Madonie resilience. 2017).

A shared integrated approach tends increasingly to produce territorial plans based on optimisation (rather than simply protection) of territorial identity as an asset that can generate a new design of a space with no specific geographic restrictions, which is able to run its life cycle in a 
sustainable way, harmonising economic, social, natural, cultural, aesthetic components with each other for a resilient wealth production (Magnaghi, 2013).

This has been a pillar for the local development strategy of the Madonie inner area, which chose not to rely above all on large public investments, but to exploit endogenous energies, to restore the vitality of local communities reinforcing the demographic, entrepreneurial and occupational rate of inner areas within the knowledge economy paradigm.

A transdisciplinary conceptual framework has been developed, new governance models (union of municipalities, participatory foundation) have been studied, business models for the sustainable consumption and production of resources have been analysed.

Through a participatory approach, the community engagement resulted into an increased awareness of its proactive role in the implementation of inclusive and sustainable local development process and its resilience in front of globalisation challenges.

\section{FoTRRIS approach for co-creation}

The FoTRRIS project aimed to foster a transition of the existing Research \& Innovation (R\&I) system to a Responsible Research and Innovation (RRI) system, as it is estimated that the current R\&I system is not as responsible as it should be. The project had an objective to offer efficient and effective methods for knowledge actors (researchers, citizens, businesses and policy-makers) to solve local challenges in a co-RRI way. The methodology of the project based on the implementation of transition arenas associated with a support of an intemediate unit called for a competence cell. According to the project, transition arenas were groups of actors interested in co-solving a local challenge, and the competence cell was an intermediate unit between all knowledge actors consisting of trained researchers in co-RRI methodologies who shared their know-how with transition arena members and facilitated the co-creation process (FoTRRIS, 2018).

As a result, transition experiments were organised in five partner countries (Austria, Belgium, Spain, Hungary and Italy), as a bottom up initiative, which targeted different topics (material scarcity, energy, food and others) aiming to co-create solutions for these glocal challenges. As Grimescu says, the bottom up approach has a deeper interest in sustainable change in a local system, as this system is a complex pull of social problems and actors, who have specific knowledge and interests to solve them, creating value (not only economic, but social and political) (Gramescu, 2016).

The framework for such co-creation work is explained by M. Deblonde:

"(1) the focus shifts from the "novelty" of scientific and technological research activities to the factual and normative situational characteristics of local sustainability challenges;

(2) the filter shifts from the exact sciences as the dominant source of scientific knowledge and technological know-how, to the social sciences, the humanities, and the natural and engineering sciences as potential sources of knowledge and know-how;

(3) responsibility expands to both formal and informal knowledge actors as providers of both theoretical and practical insights and both global and local normative ambitions" (Deblonde, 2015).

Within the FoTRRIS project, the co-creation process of innovations in different EU territories and local conditions, has been analysed, highlighting the relevance of RRI practices and models. FoTRRIS focused on glocal challenges (local evidence of global challenges and local opportunities for solving them). Then, it performed transition experiments in the pilot territories to support the transformation of current research and innovation strategies into collaborative, co-created activities (co-RRI), operated locally by competence cells for commons.

As a structured framework for unravelling lock-ins and facilitating transition, Mapping Innovations on the Sustainability Curve (MISC) methodology was applied, consisting in a dynamic map reflecting the structural characteristics of sustainable systems and sustainability curve.

This framework helps to find out missing links and leverage points in a transdisciplinary and participatory context, and results into an "ecosystem" of possible transition initiatives. The MISC addresses 'social' causes of global crisis. In fact, MISC-methodology concerns the economy in general as a "social construction" that needs redefining with a view to avoiding both social and ecological damage. The sustainability curve allows knowledge actors to reflect on existing problems and propose new solutions for policy arena (Snick, 2016). 


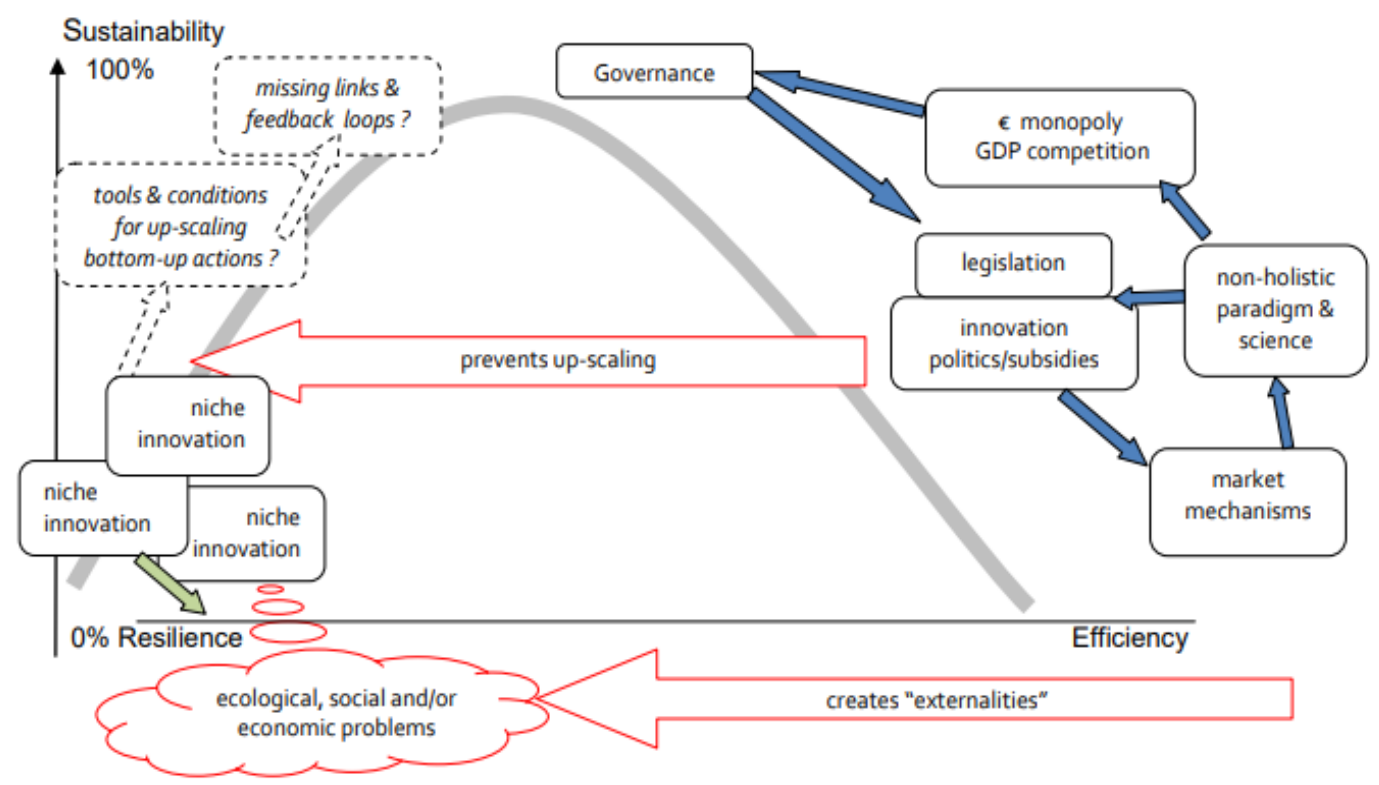

Figure 1. Basic outline / example of a MISC-map (source: Snick, 2016)

The "fittest" networks appear to be established through a high level of both efficiency and resilience. Efficiency is characterised by streamlining and standardisation, whereas resilience depends on sufficient diversity and interconnectivity, allowing the system to switch to other paths or solutions when a change occurs. A system is highly sustainable if it maintains a balance between resilience and efficiency, parameters which in turn are based on a balanced level of structural diversity and interconnectivity. Sustainability needs transdisciplinary innovation including knowledge actors and innovators outside the formal structures (Dedeurwaerdere, 2013). Knowledge actors should understand transdisciplinarity as an extension of interdisciplinary forms of the problem-specific integration of knowledge and methods; "integration of it refers to scientific questions at the interface of different disciplines in interdisciplinarity, in transdisciplinarity, on the other hand, it is about integration at the interface of these scientific questions and societal problems." (Jahn, Bergmann, \& Keil, 2012). This reinforces the role of non-institutional innovators and the disruptive power of out-of-the-box innovation niches in their interaction with policy makers to enhance local development processes.

\section{Application of RRI approach and MISC frawework for Madonie Case}

The RRI concept in the Madonie transition experiment in Sicily called for a tight cooperation among knowledge actors (researchers, citizens, policy makers, business, third sector organisations, etc.), with the aim to introduce the values, needs and expectations of local communities as the real drivers of the R\&I process.

At the initial stage the transition experiment targeted finding solutions to support local community in sustainability within the energy sector.

Multiactor and public engagement initiatives have been carried out to enable circulation of knowledge and informal learning process. The process has been driven from the consciousness that research and innovation systems, in order to address the big territorial challenges, have to face a transition phase where comprehensive collaborative practices should be introduced. Both social and economical trends must be considered, during the R\&I process, as a guide for the optimisation of resources, the orientation of impacts, the evaluation of outcomes.

In the Madonie transition experiment a collaborative RRI approach has been introduced, particularly in the design and early implementation phase of a Living Lab as catalyser of innovative sustainable processes: challenges, innovation niches, enabling technologies, market opportunities have been identified through an interaction with local authorities, local companies, professionals, trainers, technology providers. Such an ongoing interaction, if properly managed and supported, can gradually evolve into a smart, resilient community, and 
finally into a full developed innovation ecosystem, where knowledge flows, technical solutions and business opportunities are tightly interconnected and each is deeply influencing the others.

The RRI concept is strongly interconnected with the "living lab" approach. As a matter of fact, the availability of demos within the local innovation hub, as a result of the RRI process, will make possible to consolidate the collaborative innovation actions, implementing smart, efficient and resilient community. The adoption of a responsible research and innovation approach may generate sustainable technological applications and a systemic approach in which the advantage for the system has spillover effects on each component of the system itself.

The added value of the MISC approach is that the system goal has been jointly defined by researchers/local development agents and transition actors. The sustainability curve has been considered with great interest: the cultural change of mind is triggering the trend to replace the externalisation of functions (administrators vs.citizens, producers vs. consumers, from ownership to service etc...) in the capital economy with the internalisation of functions (prosumers) in the network economy as a key to implement the sustainability curve achieving efficiency and resilience.

The relations among institutional and informal innovation actors have been analysed and further developed. The respective contributions have been made complementary and synergistic within an ecosystem of solutions.

Piloting the case in the energy sector, actors from the quadruple helix invited in the transition experiment workshops have presented some pioneering experiences or innovative ideas for energy challenges, on which to build a new energy vision as leverage for change.

\section{Role of the competence cell}

EU R\&I landscape should follow the UN sustainable development goals as a global framework, mobilising different actors, supporting actions across disciplines, sectors, institutions. "Innovation laboratories of change" should be promoted, as units, which pilot RRI ideas and concepts. Co-creation is stimulated by EU as an engine, which stimulates cross-border collaborations and shape the future (EU, 2017). In FoTRRIS case, such laboratory was the competence cell, which targeted several aims:
"1) to start up dialogues between knowledge actors that engage themselves for specific glocal sustainability challenges, (2) to support the codefinition of action-research projects that aim at solving the sustainability challenge, (3) to support the composition of transdisciplinary project teams that are fit for the performance and monitoring of the co-defined research activities, (4) to make ongoing research activities and results publicly accessible so that interested persons can question and comment on them, (5) to document and archive project activities and results in order to make them accessible for further RRI activities" (Deblonde 2015).

In the Madonie case, the local competence cell including different actors, engaged in the energy transition experimental process. Three one-day long co-creation workshops were organised in the period of January-April, 2017. All of them had different goals: (1) to define lock-ins of local R\&I system, (2) to co-create innovative solutions for glocal challenge, (3) to develop a project concept for a glocal challenge. As a result, the guidelines for a rural Living Lab on sustainable development have been drawn up and, a network of qualified resources has been consolidated.

This network capitalised on and further developed the consulting, participatory and concerted actions experience launched within the drafting process of the National Strategy of Inner Areas (SNAI), facilitated from local development agency SOSVIMA.

It used the Living Lab approach to establish MaLL-Madonie Living Lab as an overall methodological framework to facilitate the participatory planning process, involving different groups of stakeholders - citizens, administrators and local companies - in the co-creation and joint development of platforms and services connected to glocal challenges and in the establishment of a smart and green community.

After the transition experiment, MaLL defined in details its concept: a) to support local communities through participation in experimenting new approaches to responsible research, innovation and entrepreneurship; b) to provide equipped spaces and facilities to allow competence and experience sharing; c) to match the demand of local communities for strategic planning of sustainable development, quality of life improvement and smart management of local resources. As a result, in 2017 MaLL's project received full acknowledgement from ENoLL- 
European Network of Living Lab (Parisi \& Montagnino, 2017).

RRI has inspired the innovation process design in MaLL to link the innovation topics to effective local needs, to foster open consultation of stakeholders, to promote user-driven ideageneration supported by an open innovation platform, to set up dedicated innovation labs to accelerate solution development and validation by final users.

The process for the implementation of the RRI approach in the Living Lab will include four main pillars:

1. Vision at the political and administrative level, participation to maximise local value creation, community empowerment.

2. Knowledge and design thinking (analysis of data, promotion of idea-generation initiatives).

3. Demonstration of appropriate technologies in relevant, open environments.

4. Business models (attracting investors and partners, project financing and crowfunding, cross-sector engagement, coownership).

As a cross-cutting action, awareness raising and story-telling to keep the memory of lessons learnt from success and failure will be carried out.

During the transition experiment in the Madonie area, the co-creation workshops have poduced the follow:

- goal setting (how to catalyse the contribution of formal and informal innovators to foster energy transition and ensure a better quality of life in rural areas, while reducing the consumption of natural resources and the big capital investments), innovation niches mapping, system lock-ins and leverages identifying.

- what needs to be done to bring about the change: future scenario design using as leverage the potential identified (governance, innovation, community resilience, efficient use of resources, cooperation) and inventory of solutions.

- project co-design to implement the vision and sustainability analysis, strategic alliances to ensure a consistent and responsible answer to glocal challenges, Force Field analysis. They have adopted a territorial development model centered around the concepts of collective creativity, entrepreneurial discovery, local actors' mobilisation, regeneration of value chains, cultural anchoring (Creative MED, 2014).

Knowledge should be the main lever to economic development; in most alliances built up to govern territorial development in inner areas the leadership is either in the hands of economic actors or public authorities, with a limited and onthe-spot support from the research and innovation system, which on the contrary should inspire and facilitate the process in all its steps within durable partnerships. The local community can extract knowledge from various trans-local actors and facilitate its transmission in collective decisions taken for territorial development, driving intangible factors nested in territories to a positive impact on local productivity and social wealth.

This strategy would reallocate inner areas in a strategic position, stressing that they are not underperforming areas targeted by a social policy, but they can contribute to a large share of regional and national growth and to value that can be profitably exchanged with the urbanised communities (OECD, 2013).

\section{Conclusions}

The Madonie experience in Italy proved to be an effective and successful application of an inclusive and sustainable territorial development policy in line with 2030 EU Agenda.

In the view of a smart and green community, the National Strategy for Inner Areas in its pilot application to Madonie used RRI as a methodological framework leverage to facilitate the process of participatory planning and to experiment and consolidate the involvement of citizens, administrators and companies in codesign of platforms and services for sustainable and inclusive development. The Living Lab project resulting from this process will represent a smart observatory of citizens with reference to the realisation of advanced systems of analysis and processing of data at a territorial scale for governance support, as well as to the pro-active participation of civil society in the protection of land and reduced consumption of resources. It will support experimentation and demonstration through pilot systems, facilitating the integration of productive chains, participatory business models, exchange of expertise to support executive design and planning and transformative process of projects/ideas into objects. It will foster creativity and sense of ownership of local resources, strengthening territorial identity and 
social cohesion. The competence cell was a core characteristic of the local co-creation process, as it guaranteed pro-active behaviour of all participants of the workshops and it helped to finalise co-creation process with a real result Madonie Living Lab concept. To get such results, the competence cell should be a transdisciplinary unit, but even more, people with specific knowledge (such as project development) should be a part of it, as only in this case, the idea can become a reality. The presented result is an example of open social innovation, as different elements of both social and open innovations were introduced in the process, and open social innovation has right to live as a concept on EU R\&I landscape.

The case of Madonie in Sicily may be a paradigm for an integrated approach to development which goes beyond internal policy coordination and traditional rural issues, with distinctive, place-based innovation indicators measuring the feasibility, effectiveness and sustainability of endogenous solutions to global challenges. It is a good example of a rural ecosystem, matching the social, environmental and economic dimensions to ensure durable development, which has achieved better cooperation between different knowledge actors, initiated collaborative practices and created solidarity networks, trying to close cycles between production and consumption, to operate changes in lifestyles, and build up an institutional capacity through different decision-making levels.

\section{Acknowledgements}

We thank the participants in the Sicilian transition arena and local development agency SOSVIMA, who invested their time and knowledge into the development of the Madonie Living Lab project proposal and ARCA, which became a part of CESIE's competence cell for testing FoTRRIS hypothesis with the local community of the Madonie.

\section{Funding}

This article is a result of the activities undertaken in the frame of the project 'Fostering Transition towards Responsible Research and Innovation Systems' (FoTRRIS). For more information, please visit project website www.fotrris-h2020.eu.

This project has received funding from the European Union's Horizon 2020 Research \&
Innovation programme [Grant Agreement no. 665906].

\section{Disclosure Statement}

No conflict of interest was reported by the authors.

\section{References}

AA.VV. (2017). Strategy for Madonie resilience. Coordinamento Tecnico dell'Area Interna Madonie 2017. Strategia d'Area. Madonie Resilienti: Laboratorio di Futuro.

AA.VV. (2014). White paper. The creative MED model for smart specialisation. Retrieved from http://www. creativemed.eu/images/pdf/CreativeMEDWhitePaper. pdf

Annan-Diab, F., \& Molinari, C. (2017). Interdisciplinary: Practical approach to advancing education for sustainability and for Sustainable Development Goals. The International Journal of Management Education, $1-11$.

Chesbrough, H. W. (2003). Open innovation: The new imperative for creating and profiting from technology. Boston: Harvard Business School Press. ISBN 9781578518371.

Deblonde, M. (2015). Responsible research and innovation: building knowledge arenas for glocal sustainability research. Journal of Responsible Innovation, 2(1), 2038. https://doi.org/10.1080/23299460.2014.1001235

Dedeurwaerder, T. (2013). Sustainability science for strong sustainability. Retrieved from http://biogov.uclouvain. be/staff/dedeurwaerdere/2013\%2001\%2011_sustainab ility $\% 20$ science-EN.pdf

European Commision (EC). (2017). LAB-FAB-APP. Investing in the European future we want. Report of the independent. High Level Group on maximasing the impact of EU Research and Innovation Programme. Retrieved from http://ec.europa.eu/research/ evaluations/pdf/archive/other_reports_studies_and_do cuments/hlg_2017_report.pdf

European Commission's Directorate-General for Research \& Innovation (EC RTD). (2015). Open Innovation, open science, open to the World - a vision for Europe. Retrieved from https://ec.europa.eu/digital-singlemarket/en/news/open-innovation-open-science-openworld-vision-europe

European Environmental Agency. (2015). Towards global sustainability. Retrieved from https://www.eea. europa.eu/articles/towards-global-sustainability

Fostering Transition towards responsible research and innovation system. (n.d.). FoTRRIS project concept. Retrieved from http://fotrris-h2020.eu

Gramescu, L. (2016). Scaling social innovation in Europe: An overview of social enterprise readiness. ProcediaSocial and Behavioral Sciences, 221, 218-225. https://doi.org/10.1016/j.sbspro.2016.05.109

Jahn, T., Bergmann, M., \& Keil, F. (2012). Transdisciplinarity: between mainstreaming and marginalization. Ecological Economics, 79, 1-10.

https://doi.org/10.1016/j.ecolecon.2012.04.017 


\section{TERRITORIAL DEVELOPMENT: THE MADONIE CASE}

Magnaghi, A. (2013). Riterritorializzare il mondo. Firenze Università. Press ISSN 2284-242X (online), n. 1, 4758. Retrieved from http://www.fupress.net/ index. $\mathrm{php} / \mathrm{SdT} /$ article/view/14265/13245

Martins Montreiro, T. S., \& Henrique de Souza Bermejo, P. (2015). Open social innovation. Economics: concepts, methodologies, tools, and applications.

Matei, A., \& Antonie, C. (2015). Complexity theory and the development of the social innovation. Procedia Social and Behavioral Sciences, 185, 61-66. https://doi.org/10.1016/j.sbspro.2015.03.371

Mejlgaard, N. (2018). Science's disparate responsibilities: Patterns across European countries. Public Understanding of Science, 27(3), 262-275.

https://doi.org/10.1177/0963662517724645

Nicholls, A., \& Dees, G. (2015). Social innovation. The international encyclopaedia of social and behavioural science $\left(2^{\text {nd }}\right.$ ed.). Elsevier. https://doi.org/10.1016/B978-0-08-097086-8.73105-9

Öberga, C., \& Alexanderc, A. T. (2018). The openness of open innovation in ecosystems - Integrating innovation and management literature on knowledge linkages. Journal of Innovation \& Knowledge. Retrieved from https://www.sciencedirect.com/science/article/pii/ S2444569X18300131 https://doi.org/10.1016/j.jik.2017.10.005

OECD. (2013). Rural-urban partnerships: An integrated approach to economic development. Retrieved from http://www.oecd.org/economy/rural-urban-partnerships-an-integrated-approach-to-economic-development.htm. https://doi.org/10.1787/9789264204812-en

Parisi, E., \& Montagnino, F. M. (2017). Madonie living lab. Retrieved from http://www.openlivinglabs.eu/livinglab/madonie-living-lab

Snick, A. (2016). MISC: Mapping innovations on the sustainability curve. A methodological framework to accelerate the transition. Retrieved from http://cesie.org/media/MISC-methodological-framework.pdf

Snick, A. (2017). EU Politics for sustainability: systemic lock-ins and opportunities. Retrieved from http://fotrris-h2020.eu/wp-content/uploads/2014/11/ Libro-Snick-Def-ver2..pdf

United Nations. (2015). Resolution adopted by the General Assembly on 25 September 2015. Transforming our world: the 2030 Agenda for Sustainable Development. Retrieved from http://www.un.org/ga/search/view_ doc.asp?symbol=A/RES/70/1\&Lang=E

Von Schomberg, R. (2013). A vision of responsible innovation. In R. Owen, M. Heintz, \& J. Bessant (Eds.), Responsible innovation. London: John Wiley. Retrieved from https://www.researchgate.net/ publication/242071460_A_vision_of_responsible_inn ovation. https://doi.org/10.1002/9781118551424.ch3 